\title{
EARTHWORMS IN SOUTHERN NORTH ISLAND HILL PASTURES
}

\author{
M.G. LAMBERT \\ Grasslands Division, DSIR,
}

Palmerston North.

\section{Abstract}

Earthworm populations were measured in hill pastures, near Woodville, which were rotationally grazed or set stocked by sheep, or rotationally grazed by cattle. For each grazing management there were two fertiliser treatments: high and low superphosphate application, and sampling sites were located within each of three slope and three aspect classes. Earthworm weight was greater in sheep-grazed than in cattle-grazed areas $\left(91\right.$ vs $\left.45 \mathrm{~g} / \mathrm{m}^{2}\right)$, was higher in high than in low fertiliser areas $\left(93\right.$ vs $\left.75 \mathrm{~g} / \mathrm{m}^{2}\right)$, and declined with increasing slope of measurement site. There was also a greater number of earthworms in sheep-grazed compared with cattle-grazed areas $\left(645 \mathrm{vs} 270 / \mathrm{m}^{2}\right)$, earthworm numbers declined with slope, and aspect influenced earthworm numbers (SW $<N W, E$ ). Allolobophoro caliginosa was $78 \%$ of total earthworm weight, the remainder was Lumbricus rubellus. This percentage was affected by grazing management. The major factor influencing size of the earthworm populations was pasture production $(r=0.42)$, although soil organic matter $(r=0.32)$ and nitrogen $(r=0.22)$ contents pasture production ( $r=0.42)$, although soll organic matter $(r=0.32)$ and nitrogen $(r=0.22)$ contents $\mathrm{DM} / \mathrm{ha}$ annual pasture production. This value was influenced only by grazing management, so production. This value was influenced only by grazing management, so was constant across a wide range of sites. Practical implications include: rotational grazing with high stock densities may reduce earthworm populations because of treading damage; and increasing existing earthworm populations in similar hill soils, other than by increasing pasture productivity, will be difficult.

Keywords: Earthworms, Allolobophora caliginosa, Lumbricus rubellus, grazing management, fertiliser, slope, aspect, soil fertility, pasture production, hill country.

\section{INTRODUCTION}

Earthworms in pastoral soils feed on dead or decaying herbage and roots, and on dung of grazing animals (Russell 1973). In sheep-grazed pastures Allolobophora caliginosa, the most common species in New Zealand, feeds predominantly on soil and dead roots, and the surface-feeding Lumbricus rubellus consumes mainly dead leaf and dung (Keogh 1979).

Beneficial effects of earthworms in soils include increased nutrient cycling through incorporation of litter into the topsoil, partial digestion of organic material, and improved soil structure (Russell 1973). Effects on soil structure, which occur through their casting and burrowing activity, improve infiltration of rainfall and soil moisture storage (Stockdill and Cossens 1966).

Introduction of earthworms to pastoral soils previously earthworm-free, has been shown toincrease pasture productivity (Stockdill 1966; Stockdill and Cossens 1966). Size of earthworm populations is positively associated with annual production of herbage (Waters 1951; Sears and Evans 1953; Suckling 1975).

A grazing trial in hill country presented an opportunity to study effects of fertiliser, grazing management, and topography on earthworm populations.

\section{METHODS AND MATERIALS}

Earthworm populations were sampled in September 1979, within the Ballantrae Grazing Trial located in steep hill country near Woodville (Lambert et al. 1983). Experimental treatments were low fertiliser (LF) application (1000 kg/ha superphosphate since 1973) and high fertiliser (HF) application (3125 kg/ha superphosphate equivalent since 1973 , plus $1250 \mathrm{~kg} / \mathrm{ha}$ lime in 1975); and three grazing managements: rotational grazing by sheep (RGS) or cattle (RGC), and set stocking by sheep (SSS). Rotational mobs were shifted three times each week. SSS treatments were replicated three times at each fertiliser level, and the trial consisted of 10 self-contained farmlets 
TABLE 1: Earthworm Live Weight $\left(\mathbf{g} / \mathrm{m}^{2}\right)$ and Number $\left(\mathbf{n o} . / \mathrm{m}^{2}\right)$, and Pasture Production (t DM/ha/yr), As Influenced by Fertiliser and Grazing Treatments, Microtopographical Site, and Aspect.

\begin{tabular}{|c|c|c|c|c|c|c|c|c|c|c|c|c|}
\hline & & \multicolumn{2}{|c|}{ Fertiliser } & \multicolumn{3}{|c|}{ Management } & \multicolumn{3}{|c|}{ Slope } & \multicolumn{3}{|c|}{ Aspect } \\
\hline & & L F & H F & $\mathbf{s ~ s ~ s}$ & RGS & RGC & I-12” & $13.25 "$ & $>26 "$ & E & NW & SW \\
\hline Total earthworms & $\begin{array}{c}\text { weight } \\
\text { (number) }\end{array}$ & $\begin{array}{c}75 \\
\langle 526\rangle\end{array}$ & $\begin{array}{c}93\left(^{\star}\right) \\
(644) n 5\end{array}$ & $\begin{array}{c}95 \\
(684)\end{array}$ & $\begin{array}{c}86 \\
(605)\end{array}$ & $\begin{array}{c}\left.455^{*}\right) \\
(270)^{*}\end{array}$ & $\begin{array}{c}97 \\
(712)\end{array}$ & $\begin{array}{c}88 \\
(591)\end{array}$ & $\begin{array}{c}66^{* \star *} \\
(453)^{\star \star *}\end{array}$ & $\begin{array}{c}85 \\
(643)\end{array}$ & $\begin{array}{c}89 \\
(601)\end{array}$ & $\begin{array}{c}78 \mathrm{~ns} \\
(512)^{*}\end{array}$ \\
\hline A. caliginosa & $\begin{array}{c}\text { weight } \\
\text { (number) }\end{array}$ & $\begin{array}{c}60 \\
(449)\end{array}$ & $\begin{array}{c}74 \\
(538) \mathrm{ns}\end{array}$ & $\begin{array}{c}80 \\
(596)\end{array}$ & $\begin{array}{c}63 \\
(482)\end{array}$ & $\begin{array}{c}31^{*} \\
(200)^{*}\end{array}$ & $\begin{array}{c}77 \\
(607)\end{array}$ & $\begin{array}{c}71 \\
(499)\end{array}$ & $\begin{array}{c}53^{\star * *} \\
(375)^{\star * *}\end{array}$ & $\begin{array}{c}68 \\
539\end{array}$ & $\begin{array}{c}70 \\
601\end{array}$ & $\begin{array}{l}63 \mathrm{~ns} \\
512^{*}\end{array}$ \\
\hline L. rubellus & $\begin{array}{c}\text { weight } \\
\text { (number) }\end{array}$ & $\begin{array}{c}14 \\
(77)\end{array}$ & $\begin{array}{c}19 \mathrm{~ns} \\
(106) \mathrm{ns}\end{array}$ & $\begin{array}{c}15 \\
(88)\end{array}$ & $\begin{array}{c}24 \\
(123)\end{array}$ & $\begin{array}{c}14 \mathrm{~ns} \\
(71) \mathrm{ns}\end{array}$ & $\begin{array}{c}20 \\
(105)\end{array}$ & $\begin{array}{c}17 \\
(92)\end{array}$ & $\begin{array}{c}13^{*} \\
(78) \mathrm{ns}\end{array}$ & $\begin{array}{c}16 \\
(104)\end{array}$ & $\begin{array}{c}19 \\
(90)\end{array}$ & $\begin{array}{c}15 \mathrm{~ns} \\
\text { (80) ns }\end{array}$ \\
\hline $\begin{array}{l}\text { Pasture } \\
\text { production }\end{array}$ & & 10.3 & $12.4^{\star *}$ & 11.5 & 12.0 & $10.2\left(^{*}\right)$ & 14.8 & 11.3 & $8.0^{\star \star \star}$ & 11.9 & 11.6 & $10.5^{* *}$ \\
\hline
\end{tabular}

$\left({ }^{\star}\right),{ }^{*}, * * * * * \mathrm{P}<0.01,0.05,0.01$ and 0.001 respectively; ns -not significant 
of 7-14 ha. Stocking rates, which were increased in annual increments from 6 su/ha in 1975. were 9.9 and $13.3 \mathrm{su} /$ ha on LF and HF areas respectively.

Soils are Yellow Brown Earths, intergrades to Yellow Grey Earths, and related steepland soils, formed on tertiary sediments (J.D. Cowie pers. comm.) under an annual rainfall of approximately $1280 \mathrm{~mm}$. Soil $\mathrm{pH}$ was 5.3 and 5.4 in LF and HF areas respectively, and Olsen $\mathrm{P}$ was 7 and $11 \mu \mathrm{g} \mathrm{P} / \mathrm{g}$ soil. Pasture botanical composition was $42 \%$ low-fertility-tolerant grasses (e.g. browntop Agrostis capillaris), $40 \%$ highfertility-responsive grasses (e.g. ryegrass Lolium perenne), $12 \%$ legumes (principally white clover Trifolium repens) and $6 \%$ weeds.

Duplicate sample sites were located in each farmlet within each of nine slope-aspect strata (slope classes $=1.12^{\circ}, 13-25^{\circ},>26^{\prime \prime}$; aspect classes were centred around E, $\mathrm{SW}, \mathrm{NW}$ ). This gave 18 sample sites per farmlet, or a total of 180 sites. Six soil cores, $16 \mathrm{~cm}$ diameter to a depth of $15 \mathrm{~cm}$, were taken from each site. Earthworms were extracted in the laboratory using a formalin technique (Springett 1981), counted, oven dried at $105^{\circ} \mathrm{C}$ and weighed. No special effort was made to ensure gut contents were eliminated before drying. Earthworm dry weight was $22 \%$ of wet weight, and this factor was used to convert measured dry weights to live weights.

Pasture production was measured at the same sites, as part of another study (Lambert et al. 1983), as was soil nitrogen and organic matter content, carbon to nitrogen ratio, $\mathrm{pH}$, bulk density, and plant available phosphorus (Olsen test).

\section{RESULTS}

Earthworm weight was greater in sheep-grazed than in cattle-grazed areas, was higher in HF than in LF soils, and declined with increasing slope of measurement site (Table 1). There was also a greater number of earthworms in sheep-grazed compared with cattle-grazed areas. Number of earthworms increased with decreasing slope, and was less on the SW than on NW or E aspects.

Of the soil factors considered, organic matter $\left(r=0.32^{* *}\right)$ and nitrogen $\left(r=0.22^{*}\right)$ content were correlated with earthworm weight. However, the strongest correlation was with pasture production $\left(\mathrm{r}=0.42^{* *}\right)$ and effects of treatments and topography on pasture production were similar to effects on earthworm number and weight (Table 1).

A. caliginosa contributed, on average, $78 \%$ of total earthworm weight. This percentage varied with management $(\mathrm{SSS}(84 \%)>\mathrm{RGS}(72 \%)=\mathrm{RGC}(69 \%)$ lsd $.05=11 \%$ ) but was not influenced by fertiliser, slope or aspect.

\section{DISCUSSION}

The organic material upon which earthworms feed is derived from pasture, so the size of earthworm populations would be expected to be related to pasture productivity. Soil organic matter and nitrogen content were also positively associated with pasture productivity. Earthworm weight increased by an average of $76 \mathrm{~kg} / \mathrm{ha}$ per $1000 \mathrm{~kg}$ pasture DM production. This value was similar across the diverse sample sites, the only significant effect $(\mathrm{P}<0.1)$ being that of grazing management: RGC(44) < RGS(76) and SSS(83). The RGC pastures were more open and erect than sheepgrazed pastures, and the severe pugging which occurred in late winter-early spring (Lambert et al. 1983) probably restricted earthworm activity. Thus, with the exception of the extreme RGC management treatment, it seems that food supply was the major factor governing size of earthworm populations. This suggests that $L$. rubellus bettersurvived trampling damage. It is surprising that percentages of the different earthworm species were influenced by grazing management but not by slope of sample site. Flatter sites have much higher dung inputs (Gillingham 1980) and treading pressure (Rumball 1966) than steeper sites, conditions under which the dung-consuming $L$ rubellus might be expected to be relatively more numerous. Sears and Evans (1953) remarked that liveweight of earthworms below, and of sheep above, a pasture would be 
similar, however this was not the case at Ballantrae. Earthworm liveweight was 800 and $1020 \mathrm{~kg} / \mathrm{ha}$ for sheep-grazed LF and HF areas respectively, and sheep liveweight 560 and $760 \mathrm{~kg} / \mathrm{ha}$ i.e. total earthworm liveweight was 1.4 times that of sheep. This is not unexpected, as far more plant material passes through the decay and decay path than through the animal consumption path in grazed hill pastures (Lambert et al. 1982). It should be noted that earthworm populations fluctuate greatly throughout the year (e.g. Waters 1955) so usefulness of a single annual measurement of earthworm populations is limited. In this case, sampling may have been after peak winter activity.

Lambert et al. (1985) found that runoff from catchments at Ballantrae was lower for HF than LF areas. They suggested that infiltration rates were higher in HF areas. The larger earthworm populations in the HF areas and the resultant greater burrowing activity support this suggestion.

Intensive rotational grazing with cattle halved earthworm populations, but rotational grazing with sheep did not have a significant effect. More intensive sheep management systems e.g. longer rotation lengths than the 60 days used at Ballantrae, or daily shifts as opposed to the two and three day shifts at Ballantrae, could detrimentally affect earthworm populations because of increased treading damage at higher stocking densities.

Where earthworms are absent in soils, introduction should stimulate decomposition processes and nutrient cycling, and increase pasture production. Introduction of additional worm species may also be beneficial through occupation of previously unoccupied niches in the soil. The work at Ballantrae confirms that rate of pasture and dung input to soil is a major determinant of size of earthworm populations, and suggests that direct manipulation of existing earthworth populations in hill soils, in order to encourage long-term activity, is likely to be difficult.

\section{References}

Gillingham, A.G. 1980. N.Z. J. agric. Res. 23: 313-321.

Keogh, R.G. 1979. In Proceedings of the 2nd Australasian Conference on Grassland Invertebrate Ecology. Eds T.K. Crosby and R.P. Pottinger. Government Printer, Wellington.

Lambert, M.G.; Renton, S.W.; Grant, D.A. 1982. In Nitrogen Balances in New Zealand Ecosystems. DSIR, New Zealand.

Lambert, M.G.; Clark, D.A.; Grant, D.A.; Costall, D.A.; Fletcher, R.H. 1983. N.Z. J. agric. Res. 26: 95-108.

Lambert, M.G.; Devantier, B.P.; Nes, P.; Penny, P.E. 1985. Ibid 28(3): In press

Rumball, P.J. 1966. Unpubl. M.Ag.Sci. Thesis, Massey University

Russell, E.W. 1973. Soil Conditions and Plant Growth. Longman, New York.

Sears, P.D.; Evans, L.T. 1953. N.Z.J. Sci. Techol. A35, Suppl. 1: 42-52.

Springett, J.A. 1981: Pedobiologio 21: 217-222.

Stockdill. S.M.J. 1966. Proc N.Z. Ecol. Soc.13:68-75

Stockdill, S.M.J.; Cossens, C.G. 1966. Proc. N.Z. Grassld Ass. 28: 168-183.

Suckling, F.E.T. 1975. N.Z. J. exp. Agric. 3: 351 436

Waters, R.A.S. 1951. Proc. N.Z.Grassid Ass. 13: 168-175. 